\title{
Impact of Alternative Fungicides on Grape Downy Mildew Control and Vine Growth and Development
}

Gianfranco Romanazzi, Valeria Mancini, Erica Feliziani, Andrea Servili, Solomon Endeshaw, and Davide Neri, Department of Agricultural, Food, and Environmental Sciences, Marche Polytechnic University, 60131 Ancona, Italy

\begin{abstract}
Romanazzi, G., Mancini, V., Feliziani, E., Servili, A., Endeshaw, S., and Neri, D. 2016. Impact of alternative fungicides on grape downy mildew control and vine growth and development. Plant Dis. 100:739-748.

Grapevine downy mildew (GDM) is one of the most serious diseases of grapevines. With limitations in the use of copper-based products imposed for organic agriculture by the European Union, research for alternatives is encouraged. The aim of this research was to follow a 2-year trial to evaluate the control of GDM using some alternative compounds, and to determine their effects on shoot growth, plant photosynthesis, and grape quality and quantity. Under low disease pressure, Bordeaux mixture, copper hydroxide, laminarin combined with low copper, and 0.5 and $0.8 \%$ chitosan had the lowest GDM incidence, reduced on leaves by 96 , $95,75,56$, and $81 \%$, respectively, compared with the untreated control

in the last survey. With high disease pressure, Bordeaux mixture, laminarin combined with Saccharomyces extracts, and 0.5 and $0.8 \%$ chitosan had the lowest GDM incidence, reduced on grape by $86,37,66$, and $75 \%$, respectively, compared with the untreated control in the survey of mid-July. Chitosan at $0.8 \%$ lowered net photosynthesis, due to reduced stomatal conductance, leaf area, and dry weight, with no negative effects observed on the quantity of the grape berries and the quality parameters of their juice. Among the alternatives to copper, chitosan provided the best GDM protection and reduced the vigor of the vegetation, inducing physiological changes without negative effects on grape production.
\end{abstract}

Grapevine downy mildew (GDM) is caused by the obligate biotrophic oomycete Plasmopara viticola, and it is one of the most serious diseases of grapevines worldwide (Gessler et al. 2011). It is potentially destructive, especially in Europe, where grape-growing conditions are characterized by high humidity and abundant rainfall in the spring (Caffi et al. 2010). Over the last 20 years, the most widely used technique to control this pathogen was through the application of copper compounds, particularly in organic vineyards (Speiser et al. 2000). However, the massive use of copper at rates of up to $8 \mathrm{~kg} / \mathrm{ha} / \mathrm{year}$ has led to accumulation of this heavy metal in the topsoil in many European countries (Rusjan et al. 2007). Copper that has been distributed to the soil as a result of canopy foliar sprays cannot be metabolized by soil microorganisms, and is only eliminated from the vineyard through leaching. This excessive accumulation of copper in the topsoil has resulted in decreases in the carabid and earthworm populations, caused microbiological and enzymatic alterations, lowered the soil $\mathrm{pH}$, and reduced grapevine growth (Pontiroli et al. 2001).

As a consequence of these problems, the use of copper fungicides in organic agriculture was restricted by European Union Regulation 473/2002 (European Commission 2002). This regulation limits the use of copper in organic farming to $6 \mathrm{~kg} / \mathrm{ha} /$ year in the European countries. In response to these limitations, in recent years, research into alternative products to reduce or eliminate copper-based formulations in organic agriculture has been encouraged (Gessler et al. 2011). Some studies have identified natural compounds that have shown interesting qualities in terms of GDM control, such as protein hydrolysates (Lachhab et al. 2014), chitosan (Maia et al. 2012), laminarin (Aziz et al. 2003), and microorganisms (Alfonzo et al. 2012).

Chitosan is a deacetylated form of $N$-acetyl glucosamine, and it is a common polymer in shells of crustaceans, exoskeletons of insects, and cell walls of fungi. Among its several application areas, chitosan has been shown to control preharvest and postharvest plant diseases (Romanazzi et al. 2016). Chitosan has eliciting activities that can lead

Corresponding author: G. Romanazzi; E-mail: g.romanazzi@univpm.it

Accepted for publication 29 September 2015.

http://dx.doi.org/10.1094/PDIS-05-15-0564-RE

(C) 2016 The American Phytopathological Society to a variety of defense responses to microbial infections in host plants, which include the accumulation of phytoalexins, pathogenrelated proteins, and proteinase inhibitors and the induction of lignin synthesis and callose formation (El Hadrami et al. 2010). Moreover, chitosan can also form physical barriers around the penetration sites of pathogens (Romanazzi et al. 2009), which can prevent them from spreading to healthy tissue, and fungicidal activities of chitosan have been documented against various fungi (Feliziani et al. 2013).

Among the $\beta$-1,3-glucans, laminarin was derived from the brown alga Laminaria digitata and was shown to stimulate natural defense responses in plants. Laminarin is involved in the induction of genes that encode various pathogenesis-related proteins with antimicrobial properties (Khan et al. 2009). Through its elicitation of plant defense reactions, laminarin can also reduce the development of many fungal pathogens, including P. viticola (Aziz et al. 2003).

The biological control of plant pathogens includes the use of several microorganisms. Several biocontrol agents can promote vegetative growth and induce resistance against pathogens in plants, including against phytopathogenic fungi, bacteria and viruses, and, in some cases, pest insects and nematodes (Harman et al. 2004; Liu et al. 2007). Some microorganisms were reported to be active against grapevine fungal pathogens, including $P$. viticola (Alfonzo et al. 2012; Burruano et al. 2008).

The present study evaluated the effectiveness of weekly foliar applications using natural compounds aimed at controlling GDM. Compounds evaluated were laminarin, bentonite, vermicompost extracts, and chitosan, plus some biocontrol agents, including Saccharomyces extracts and rhizosphere microorganisms such as Glomus spp., Bacillus subtilis, Streptomyces spp., Trichoderma spp., and Pichia pastoris. In addition, because these treatments can result in alterations to several physiological processes of the plants (Mandal et al. 2009), their influence on vine photosynthesis and vegetative and reproductive growth were also evaluated.

\section{Materials and Methods}

Vineyard treatments. The experimental field trials were conducted in 2012 and 2013 in a 6-year-old commercial vineyard of Vitis vinifera 'Montepulciano', grafted onto 420A rootstock, located at Camerano $(\mathrm{AN})$, in central-eastern Italy $\left(43^{\circ} 29^{\prime} 39.90^{\prime \prime} \mathrm{N} ; 13^{\circ} 16^{\prime} 05.91^{\prime \prime} \mathrm{S}\right)$. The plants were spaced by $1.0 \mathrm{~m}$ in the rows, with $2.2 \mathrm{~m}$ between the rows, and they were grown according to the Guyot trellis system, leaving 10 
buds per vine, with grass cover between the rows. The height of the fruiting cane was $60 \mathrm{~cm}$ from the ground. The vineyard was not irrigated, the fertilizers were distributed banded under vine in the winter, and additional hedging was applied in spring and summer, according to common practices for the areas.

Over the 2 years, 12 treatments were tested, compared with an untreated control; the active ingredients and the application rates are listed in Table 1. A randomized block design with four replicates was used, and the treatments were assigned to plots using a randomnumber generator (Excel; Microsoft Corp., Redmond, WA). Each plot consisted of seven grapevines along a row, and the treated rows were separated from each other by an untreated row. The treatments tested in both the years were applied to randomly selected vines between the different years.

Treatments began on 14 May 2012, and 15 May 2013, when the plants started to be sensitive to GDM infection. At the time of first product application, plants were at the phenological stage of inflorescences swelling (BBCH 55) and the shoots were about $20 \mathrm{~cm}$ long. Treatments were repeated weekly until the end of July, with a total of 11 applications per year. The treatments were distributed by spraying a volume equivalent to 1,000 liters/ha, using a motorized backpack sprayer (Honda GX 25, $25 \mathrm{~cm}^{3}, 0.81 \mathrm{~kW}$; Honda, Tokyo). Throughout the experimental period, the plants were sprayed with the same compounds, except for a treatment schedule where laminarin combined with low copper was used for the first application, laminarin combined with Saccharomyces spp. extracts for the following seven applications, and laminarin again combined with low copper for the last three treatments. The treatment referred to here as bentonite $\left(2.6 \% \mathrm{~K}_{2} \mathrm{O}, 18.5 \% \mathrm{CaO}\right.$, and $\left.3.1 \% \mathrm{Mg}\right)$ included bentonite, lithothamne and potassic stone meal, and it represents a basic mixture used in biodynamic agriculture. The vermicompost extract used here is composed of Lumbricus spp. humus enriched with plant essences and it contains $3.5 \%$ of nitrogen.

Climate data. The weather parameters (i.e., mean temperature and rainfall) and the phenological stages of budbreak, bloom, and veraison were obtained from the data provided by the weather station of Camerano and from the Bollettino Agrometeorologico published by Agrometeo, ASSAM, Marche region.

Evaluation of GDM infections. Evaluation of GDM infections was carried out in all vines of each treatment on 100 leaves randomly selected per vine, and all clusters. During 2012, GDM symptoms were recorded for the grapevine leaves on $6,12,18$, and 25 June and 2, 9, 23, and 30 July, and soon after the harvest on 24 September, with the grape bunches scored on 9, 23, and 30 July and 30 August. During 2013, GDM symptoms were recorded for the grapevine leaves on 7 and 13 June and 1, 11, and $31 \mathrm{July,} \mathrm{and} \mathrm{on} \mathrm{the} \mathrm{grape}$ bunches on 11 and 31 July and 30 August. The disease incidence was expressed as the percentage of infected leaves or grape bunches. Moreover, the disease severity on the leaves was assigned to $11 \mathrm{lev}$ els, according to the percentage of surface covered by the GDM symptoms, from 0 (uninfected leaf) to 10 (over $90 \%$ of leaf surface showing symptoms). For the grape bunches, the disease severity was assigned to eight levels, according to the number of infected berries and the percentage of the grape bunch that showed symptoms, as $0=$ healthy grape bunch, $1=1$ to 5 infected berries, $2=6$ to 11 infected berries, $3=12$ to 25 infected berries, $4=25 \%$ of grape bunch showing symptoms, $5=26$ to $50 \%$ of grape bunch showing symptoms, $6=51$ to $75 \%$ of grape bunch showing symptoms, and $7=$ $>75 \%$ of grape bunch showing symptoms. The infection index (or McKinney's index), which incorporates both the incidence and severity of the disease, was expressed as the weighted means of the disease as a percentage of the maximum possible level. In detail, this was calculated according to equation (1):

$$
I=[\Sigma(d \times f) /(N \times D)] \times 100
$$

where $d$ is the category of disease intensity scored for the grapevine leaves or the grape bunches, $f$ is the disease frequency, $N$ is the total number of organs examined (healthy and rotted), and $D$ is the highest category of disease intensity that occurred on the empirical scale (McKinney 1923).

Physiological and growth parameters of grapevines. Net photosynthesis, transpiration rate, and stomatal conductance were determined on the grapevine leaves using a LcPro+ portable infrared gas analysis system (ADC, Maidstone, UK), equipped with a leafclamped cuvette for a leaf area of $6.25 \mathrm{~cm}^{2}$. The measurements were taken under field environment conditions, with photosynthetically active radiation $\geq 1,250 \mu \mathrm{mol} \mathrm{m} \mathrm{m}^{-2} \mathrm{~s}^{-1}$, incoming relative humidity fixed at approximately $26.7 \%$, and chamber temperature from 28 to $35^{\circ} \mathrm{C}$. The measurements were also carried out in the morning from 7 to 10 A.M., before the estimated "midday depression", to limit photoinhibition of the photosynthetic apparatus. The leaves on which

Table 1. Treatment formulations, application rates, and frequencies used in the present study

\begin{tabular}{|c|c|c|c|c|c|}
\hline Active ingredient (\%) & Commercial product & Supplier & Application rate & $\begin{array}{l}\text { Number of } \\
\text { applications }\end{array}$ & Trial years \\
\hline Bordeaux mixture (20) & Poltiglia Disperss & Cerexagri Italia S.r.l. (IT) & $5,000 \mathrm{~g} / \mathrm{ha}$ & 11 & 2012,2013 \\
\hline Copper hydroxide (19.2) & Funguran & Certis Europe (IT) & $2,800 \mathrm{ml} / \mathrm{ha}$ & 11 & 2012,2013 \\
\hline Laminarin & Frontiere & BioAtlantis (IRL) & $1,000 \mathrm{ml} / \mathrm{ha}$ & 11 & 2012,2013 \\
\hline $\begin{array}{l}\text { Laminarin + microbial extract of } \\
\text { Saccharomyces spp. }(10)+ \\
\text { carboxylamine }(10)\end{array}$ & Frontiere + Oomisine & BioAtlantis (IRL); Kalosgate (IT) & $1,000 \mathrm{ml} / \mathrm{ha}+2,000 \mathrm{~g} / \mathrm{ha}$ & 11 & 2012,2013 \\
\hline $\begin{array}{l}\text { Laminarin + copper hydroxide/ } \\
\text { copper oxide (33) }\end{array}$ & Frontiere + Coptrel & BioAtlantis (IRL); Kalosgate (IT) & $1,000 \mathrm{ml} / \mathrm{ha}+500 \mathrm{ml} / \mathrm{ha}$ & 11 & 2012,2013 \\
\hline $\begin{array}{l}\text { Laminarin + copper hydroxide/ } \\
\text { copper oxide (33) }\end{array}$ & Frontiere + Coptrel & BioAtlantis (IRL); Kalosgate (IT) & $1,000 \mathrm{ml} / \mathrm{ha}+500 \mathrm{ml} / \mathrm{ha}$ & 1 & 2012, 2013 \\
\hline $\begin{array}{l}\text { Laminarin + microbial extract of } \\
\text { Saccharomyces spp. }(10)+ \\
\text { carboxylamine }(10)\end{array}$ & Frontiere + Oomisine & & $1,000 \mathrm{ml} / \mathrm{ha}+500 \mathrm{ml} / \mathrm{ha}$ & 7 & \\
\hline $\begin{array}{l}\text { Laminarin + copper hydroxide/ } \\
\text { copper oxide (33) }\end{array}$ & Frontiere + Coptrel & & $1,000 \mathrm{ml} / \mathrm{ha}+500 \mathrm{ml} / \mathrm{ha}$ & 3 & \\
\hline Laminarin + microorganisms $\mathrm{z}^{\mathrm{z}}$ & $\begin{array}{c}\text { Frontiere }+ \text { Micosat } \\
\text { TAB fogliare }\end{array}$ & Kalosgate (I); CCS Aosta S.r.l. (IT) & $1,000 \mathrm{ml} / \mathrm{ha}+2,000 \mathrm{~g} / \mathrm{ha}$ & 11 & 2012,2013 \\
\hline $\begin{array}{l}\text { Bentonite, lithothamne, potassic } \\
\text { stone meal }\end{array}$ & Bentotamnio & Cerrus (IT) & $14,167 \mathrm{~g} / \mathrm{ha}$ & 11 & 2012 \\
\hline Vermicompost extract & Humixa & Farmtech (SI) & $6,000 \mathrm{ml} / \mathrm{ha}$ & 11 & 2013 \\
\hline Chitosan (99.9) & Chito Plant & ChiPro GmbH (D) & $5,000 \mathrm{~g} / \mathrm{ha}$ & 11 & 2012,2013 \\
\hline Chitosan (99.9) & Chito Plant & ChiPro GmbH (D) & $8,000 \mathrm{~g} / \mathrm{ha}$ & 11 & 2012, 2013 \\
\hline Control & Untreated & $\ldots$ & $\ldots$ & $\ldots$ & 2012,2013 \\
\hline
\end{tabular}

${ }^{\mathrm{z}}$ Microorganisms: Glomus spp., Bacillus subtilis, Streptomyces spp., Trichoderma spp., and Pichia pastoris. 
the measurements were made were selected based on their similar size and absence of GDM symptoms, and they were located on the fourth and fifth nodes of the primary shoot of each vines. For the assessments of the net photosynthesis, transpiration rate, and stomatal conductance, three recordings were taken per plot on the selected leaves when the $\mathrm{CO}_{2}$ uptake was steady. On the same leaves, three chlorophyll meter readings per leaf, one for each of the three main lobes (i.e., SPAD values), were taken. Net photosynthesis, transpiration, and stomatal conductance were measured on 19 June and 10 July 2012 and 15 July 2013. The relative chlorophyll concentrations were estimated on 7 September 2012 and 15 July and 1 August 2013, using a SPAD-502 chlorophyll meter (Minolta, Tokyo).

In the first year, measurements were also made of the leaf areas, using the LI 3100 Areameter (Li-Cor, Lincoln, NE), and the fresh and dry weights of 40 mature fully expanded leaves within a treatment replication, selected at random among the leaves taken at the fourth internode of each shoot of every plant. To determine the dry weight, leaves were placed in an oven at $75^{\circ} \mathrm{C}$ for 3 days. These parameters were evaluated for leaves treated with the Bordeaux mixture, copper hydroxide, laminarin, and $0.8 \%$ chitosan, and for the untreated ones. On 11 March 2014, the pruning weight was recorded for all of the plants for each treatment, whereas the measurements were not taken in 2013, because the shoot growth overall did not show significant differences among treatments during 2012.

In 2012, the shoot length was measured weekly, five times during the season, from the beginning of June to the first week of July, which was the last week before the green pruning which is a common practice for the area. Shoots were randomly selected at each measurement date and, in each survey, 10 shoots of each plant were measured, considering all the plants in all the plots.

Grape production. During 2012, at commercial harvest (21 September), a sample of 100 berries was collected from randomly selected clusters by clipping one or two terminal berries from the second lateral branch located at the top of the rachis of mature clusters from each plot.
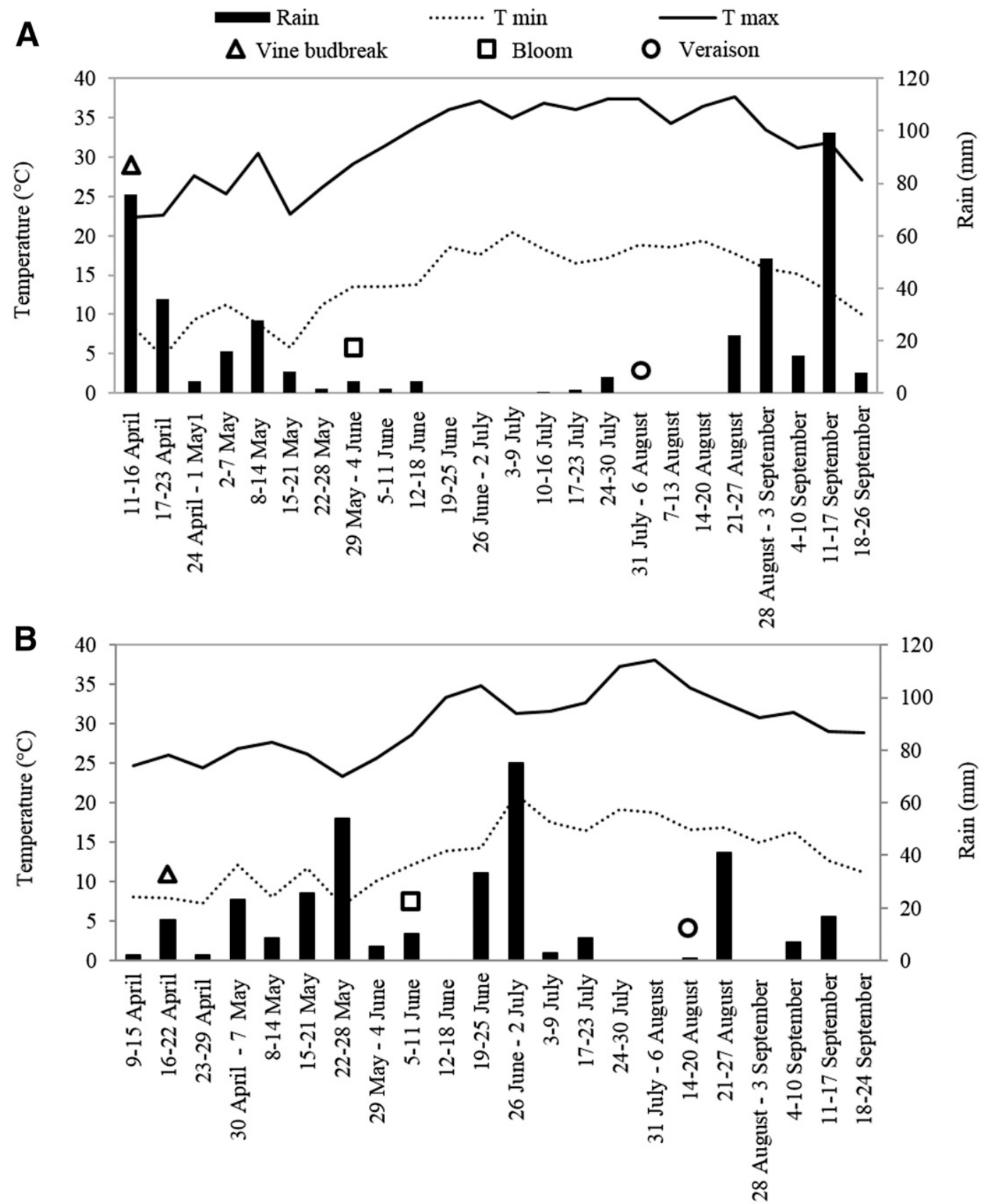
The quality parameters of the musts, including the total soluble solids ( ${ }^{\circ}$ Brix), total sugar (Babo), titratable acidity (grams of tartaric acid per liter), and pH (Howell 2001; Mira de Orduña 2010), were determined through laboratory analysis carried out by Moncaro winery. Moreover, on the day of harvest, the production per each grapevine was recorded.

Statistical analysis. The data were submitted to analysis of variance according to a randomized block design, and the means were separated by Tukey's honestly significant difference tests at $\alpha<$ 0.05 (Statsoft, Tulsa, OK). The statistical analysis to determine the homogeneity of the variance was tested using Levene's tests. The percentage data were arcsine transformed before analysis to improve the homogeneity of the variance when the range of the percentages was $>40$. Actual values are shown.

\section{Results}

Climate data. In the first year, the unfavorable climatic conditions for disease development, lasting until late August, led to a low incidence of GDM. Conversely, the rainfall from the end of August 2012 to halfway through September was favorable for the onset of late GDM infection, which occurs on the leaves (Fig. 1A).

In the second year, the abundant rainfall in spring, coincident with an increase in temperature, were favorable for the onset of GDM infection. With rainfall even during the months of July and August, the climatic

Table 2. Disease incidence (DI) and severity (Sev) and McKinney's index (MI) for the grape downy mildew infection recorded for the grapevine leaves on 23 July 2012, and on 24 September 2012, (after the grape harvest), and on the grape bunches on 23 July 2012, following the treatments with the different formulations during the season ${ }^{y}$

\begin{tabular}{|c|c|c|c|c|c|c|c|c|c|}
\hline \multirow[b]{3}{*}{ Treatment ${ }^{\mathrm{z}}$} & \multicolumn{6}{|c|}{23 July 2012} & \multirow{2}{*}{\multicolumn{3}{|c|}{$\frac{24 \text { September } 2012}{\text { Leaves }}$}} \\
\hline & \multicolumn{3}{|c|}{ Leaves } & \multicolumn{3}{|c|}{ Grape bunches } & & & \\
\hline & DI $(\%)$ & Sev (1-10) & MI (\%) & DI (\%) & $\operatorname{Sev}(1-7)$ & MI (\%) & DI (\%) & Sev (1-10) & MI (\%) \\
\hline $\begin{array}{c}\text { Bordeaux } \\
\text { mixture }\end{array}$ & $2.3 \pm 3.2 \mathrm{de}$ & $0.9 \pm 1.6 \mathrm{de}$ & $0.4 \pm 0.7 \mathrm{de}$ & $14.2 \pm 12.1 \mathrm{ab}$ & $1.3 \pm 1.5 \mathrm{ab}$ & $3.3 \pm 3.7 \mathrm{~cd}$ & $3.6 \pm 1.9 \mathrm{e}$ & $2.1 \pm 0.9 \mathrm{f}$ & $1.3 \pm 0.8 \mathrm{e}$ \\
\hline $\begin{array}{l}\text { Copper } \\
\text { hydroxide }\end{array}$ & $1.8 \pm 0.9 \mathrm{de}$ & $0.9 \pm 0.9 \mathrm{de}$ & $0.3 \pm 0.3 \mathrm{de}$ & $18.8 \pm 15.1 \mathrm{ab}$ & $1.2 \pm 1.2 \mathrm{ab}$ & $4.9 \pm 5.9 \mathrm{abcd}$ & $5.3 \pm 2.2 \mathrm{e}$ & $2.2 \pm 1.2 \mathrm{f}$ & $1.8 \pm 1.0 \mathrm{e}$ \\
\hline Laminarin & $16.3 \pm 7.0 \mathrm{ab}$ & $1.9 \pm 0.6 \mathrm{a}$ & $3.6 \pm 4.0 \mathrm{ab}$ & $33.1 \pm 32.5 \mathrm{a}$ & $1.7 \pm 1.8 \mathrm{ab}$ & $13.2 \pm 19.4 \mathrm{ab}$ & $100 \mathrm{a}$ & $8.7 \pm 1.1 \mathrm{a}$ & $84.6 \pm 14.4 \mathrm{a}$ \\
\hline $\begin{array}{l}\text { Laminarin+ } \\
\text { Ext }\end{array}$ & $6.0 \pm 4.2 \mathrm{~cd}$ & $1.5 \pm 0.6 \mathrm{abc}$ & $1.0 \pm 1.2 \mathrm{~cd}$ & $24.7 \pm 26.2 \mathrm{ab}$ & $1.8 \pm 1.5 \mathrm{ab}$ & $8.4 \pm 10.8 \mathrm{abcd}$ & $100 \mathrm{a}$ & $7.8 \pm 0.5 \mathrm{abc}$ & $66.1 \pm 18.5 b$ \\
\hline $\begin{array}{l}\text { Laminarin+ } \\
\mathrm{Cu}\end{array}$ & $2.4 \pm 1.3 \mathrm{de}$ & $1.1 \pm 0.9 \mathrm{bcd}$ & $0.3 \pm 0.3 \mathrm{de}$ & $31.1 \pm 28.5 \mathrm{ab}$ & $1.5 \pm 0.8 \mathrm{ab}$ & $9.2 \pm 10.0 \mathrm{abcd}$ & $25.2 \pm 8.6 \mathrm{~cd}$ & $4.3 \pm 1.0 \mathrm{de}$ & $11.7 \pm 6.6 \mathrm{~cd}$ \\
\hline $\begin{array}{l}\text { Laminarin+ } \\
\mathrm{Cu}+\mathrm{Ext}+\mathrm{Cu}\end{array}$ & $13.4 \pm 6.3 b$ & $1.7 \pm 0.7 \mathrm{ab}$ & $2.6 \pm 2.0 \mathrm{ab}$ & $18.2 \pm 23.5 a b$ & $1.0 \pm 1.9 \mathrm{ab}$ & $3.9 \pm 6.0 \mathrm{bcd}$ & $33.0 \pm 9.1 \mathrm{bc}$ & $5.1 \pm 0.9 \mathrm{~cd}$ & $17.7 \pm 7.6 \mathrm{~cd}$ \\
\hline $\begin{array}{l}\text { Laminarin+ } \\
\text { Mix }\end{array}$ & $21.7 \pm 13.3 \mathrm{a}$ & $1.8 \pm 0.6 \mathrm{ab}$ & $4.6 \pm 5.9 \mathrm{a}$ & $18.0 \pm 19.5 \mathrm{ab}$ & $1.2 \pm 1.4 \mathrm{ab}$ & $5.5 \pm 5.1 \mathrm{abcd}$ & $99.3 \pm 1.4 \mathrm{a}$ & $9.2 \pm 0.3 \mathrm{a}$ & $91.0 \pm 2.0 \mathrm{a}$ \\
\hline Bentonite & $14.4 \pm 1.7 \mathrm{ab}$ & $1.9 \pm 1.1 \mathrm{ab}$ & $3.0 \pm 1.8 \mathrm{abc}$ & $27.4 \pm 25.4 \mathrm{ab}$ & $2.0 \pm 1.5 \mathrm{ab}$ & $10.9 \pm 11.4 \mathrm{abc}$ & $100 \mathrm{a}$ & $8.8 \pm 0.8 \mathrm{a}$ & $80.0 \pm 23.6 \mathrm{ab}$ \\
\hline $0.5 \%$ Chitosan & $1.4 \pm 0.3 \mathrm{e}$ & $1.1 \pm 0.8 \mathrm{~cd}$ & $0.2 \pm 0.3 \mathrm{de}$ & $15.7 \pm 12.9 \mathrm{ab}$ & $1.2 \pm 0.9 \mathrm{ab}$ & $3.2 \pm 3.0 \mathrm{bcd}$ & $43.6 \pm 15.1 \mathrm{~b}$ & $5.6 \pm 0.6 \mathrm{bcd}$ & $25.1 \pm 9.8 \mathrm{c}$ \\
\hline $0.8 \%$ Chitosan & $0.7 \pm 0.6 \mathrm{e}$ & $0.4 \pm 1.0 \mathrm{e}$ & $0.1 \pm 0.2 \mathrm{e}$ & $12.9 \pm 16.8 \mathrm{~b}$ & $0.8 \pm 0.8 \mathrm{~b}$ & $2.5 \pm 3.8 \mathrm{~d}$ & $19.3 \pm 10.0 \mathrm{~d}$ & $3.5 \pm 1.0 \mathrm{e}$ & $8.2 \pm 5.9 \mathrm{de}$ \\
\hline Control & $10.9 \pm 4.0 \mathrm{bc}$ & $1.5 \pm 0.4 \mathrm{abc}$ & $1.8 \pm 1.4 \mathrm{bc}$ & $34.1 \pm 27.2 \mathrm{a}$ & $2.0 \pm 1.7 \mathrm{a}$ & $13.7 \pm 20.7 \mathrm{a}$ & $100 \mathrm{a}$ & $8.6 \pm 0.9 \mathrm{ab}$ & $78.3 \pm 20.3 \mathrm{ab}$ \\
\hline
\end{tabular}

y Data are means \pm standard deviation. Values followed by different letters in the same column are significantly different (Tukey's honestly significant difference; $\alpha<0.05)$.

${ }^{\mathrm{z}}$ Ext $=$ microbial extract of Saccharomyces spp., $\mathrm{Cu}=$ copper hydroxide or copper oxide, and Mix = microorganisms (Glomus spp., Bacillus subtilis, Streptomyces spp., Trichoderma spp., and Pichia pastoris).

Table 3. Disease incidence (DI) and severity (Sev) and McKinney's index (MI) for the grape downy mildew infection recorded for the grapevine leaves on 11 and 31 July 2013, and on the grape bunches on 11 July 2013, and 30 August 2013, following the treatments with the different formulations during the season ${ }^{y}$

\begin{tabular}{|c|c|c|c|c|c|c|}
\hline \multirow[b]{3}{*}{ Treatment $^{\mathrm{z}}$} & \multicolumn{6}{|c|}{11 July 2013} \\
\hline & \multicolumn{3}{|c|}{ Leaves } & \multicolumn{3}{|c|}{ Grape bunches } \\
\hline & DI (\%) & Sev (1-10) & MI (\%) & DI (\%) & Sev (1-7) & MI (\%) \\
\hline $\begin{array}{c}\text { Bordeaux } \\
\text { mixture }\end{array}$ & $16.3 \pm 8.5 \mathrm{c}$ & $1.7 \pm 0.1 \mathrm{~d}$ & $3.2 \pm 1.4 \mathrm{e}$ & $8.8 \pm 8.7 \mathrm{~d}$ & $1.3 \pm 1.6 \mathrm{~d}$ & $3.7 \pm 4.8 \mathrm{~d}$ \\
\hline $\begin{array}{l}\text { Copper } \\
\text { hydroxide }\end{array}$ & $54.7 \pm 25.7 \mathrm{~b}$ & $2.3 \pm 0.6 \mathrm{~cd}$ & $12.6 \pm 4.5 \mathrm{~d}$ & $51.4 \pm 15.5 \mathrm{abc}$ & $4.2 \pm 0.7 \mathrm{a}$ & $34.1 \pm 15.7 \mathrm{ab}$ \\
\hline Laminarin & $87.6 \pm 16.6 \mathrm{a}$ & $4.4 \pm 1.6 \mathrm{a}$ & $37.1 \pm 9.2 \mathrm{a}$ & $61.2 \pm 22.1 \mathrm{ab}$ & $4.3 \pm 0.9 \mathrm{a}$ & $41.3 \pm 17.0 \mathrm{a}$ \\
\hline Laminarin+Ext & $79.1 \pm 26.3 \mathrm{a}$ & $2.8 \pm 0.9 \mathrm{bc}$ & $20.6 \pm 3.7 c$ & $40.4 \pm 11.2 \mathrm{c}$ & $3.1 \pm 1.6 \mathrm{ab}$ & $19.8 \pm 14.8 b c$ \\
\hline Laminarin $+\mathrm{Cu}$ & $93.4 \pm 2.3 \mathrm{a}$ & $2.4 \pm 0.6 \mathrm{~cd}$ & $22.4 \pm 5.7 \mathrm{c}$ & $42.8 \pm 9.1 b c$ & $4.5 \pm 0.8 \mathrm{a}$ & $29.4 \pm 8.5 \mathrm{ab}$ \\
\hline $\begin{array}{l}\text { Laminarin+ } \\
\mathrm{Cu}+\mathrm{Ext}+\mathrm{Cu}\end{array}$ & $76.3 \pm 22.6 \mathrm{a}$ & $4.7 \pm 2.7 \mathrm{ab}$ & $27.9 \pm 3.5 a b c$ & $50.7 \pm 14.0 \mathrm{abc}$ & $3.7 \pm 0.9 \mathrm{a}$ & $27.7 \pm 14.4 \mathrm{ab}$ \\
\hline Laminarin+Mix & $76.7 \pm 20.4 \mathrm{a}$ & $3.9 \pm 1.3 \mathrm{a}$ & $28.4 \pm 5.9 \mathrm{abc}$ & $49.9 \pm 8.8 \mathrm{abc}$ & $3.6 \pm 0.8 \mathrm{a}$ & $27.2 \pm 9.7 \mathrm{ab}$ \\
\hline $\begin{array}{l}\text { Vermicompost } \\
\text { extract }\end{array}$ & $83.3 \pm 29.6 \mathrm{a}$ & $2.8 \pm 1.2 \mathrm{~cd}$ & $27.3 \pm 11.9 \mathrm{bc}$ & $59.5 \pm 9.3 \mathrm{abc}$ & $4.6 \pm 0.5 \mathrm{a}$ & $40.6 \pm 8.6 \mathrm{a}$ \\
\hline $0.5 \%$ chitosan & $36.9 \pm 16.6 \mathrm{bc}$ & $2.1 \pm 0.4 \mathrm{~cd}$ & $8.4 \pm 4.7 \mathrm{~d}$ & $22.2 \pm 16.1 \mathrm{~d}$ & $2.3 \pm 1.4 \mathrm{bc}$ & $11.3 \pm 13.1 \mathrm{~cd}$ \\
\hline $0.8 \%$ chitosan & $42.7 \pm 19.4 \mathrm{~b}$ & $2.0 \pm 0.4 \mathrm{~cd}$ & $9.2 \pm 4.7 \mathrm{~d}$ & $15.9 \pm 10.6 \mathrm{~d}$ & $1.7 \pm 1.3 \mathrm{~cd}$ & $7.3 \pm 9.0 \mathrm{~d}$ \\
\hline \multirow[t]{2}{*}{ Control } & $90.6 \pm 17.1 \mathrm{a}$ & $3.8 \pm 0.9 \mathrm{ab}$ & $33.4 \pm 3.4 \mathrm{ab}$ & $64.3 \pm 12.3 \mathrm{a}$ & \multirow{2}{*}{\multicolumn{2}{|c|}{$\begin{array}{c}4.3 \pm 0.3 \mathrm{a} \quad \begin{array}{c}39.3 \pm 6.2 \mathrm{a} \\
\text { (continued on next page }\end{array}\end{array}$}} \\
\hline & & & & & & \\
\hline
\end{tabular}

y Data are means \pm standard deviation. Values followed by different letters in the same column are significantly different (Tukey's honestly significant difference; $\alpha<0.05)$.

${ }^{\mathrm{z}}$ Ext $=$ microbial extract of Saccharomyces spp., $\mathrm{Cu}=$ copper hydroxide or copper oxide, and Mix = microorganisms (Glomus spp., Bacillus subtilis, Streptomyces spp., Trichoderma spp., and Pichia pastoris). 
conditions were favorable for GDM development throughout the growing season, and this led to high disease incidence (Fig. 1B).

Evaluation of GDM infection: First year. The first GDM infections appeared on the grapevine leaves on 18 May 2012. In the survey of 4 June 2012, the disease incidence was very low among all of the treatments, at $<1 \%$. The grapevines treated with copper hydroxide, laminarin combined with Saccharomyces spp. extracts, and 0.5 and $0.8 \%$ chitosan did not show any GDM symptoms (data not shown). In the following assessments, an increase in the infection levels of GDM on the leaves was recorded, with the highest values on 23 July 2012 and soon after the harvest, on 24 September 2012 (Table 2).

On 23 July, the grapevines treated with Bordeaux mixture, copper hydroxide, laminarin combined with low copper, and 0.5 and $0.8 \%$ chitosan showed significant reductions in GDM incidence compared with the control of $79,84,78,87$, and $95 \%$, respectively, as also seen for the McKinney's index of 79, 85, 81, 88, and 94\%, respectively. The disease severity was significantly reduced compared with the control by treatment with Bordeaux mixture, copper hydroxide, and $0.8 \%$ chitosan applications. All disease ratings of the grapevines treated with laminarin alone or with laminarin combined with microorganisms exceeded those of the control.

In the assessment of GDM on grape bunches carried out on 23 July, the disease incidence was significantly reduced (by 62\%) compared with the control only by treatment with $0.8 \%$ chitosan. The McKinney's index of GDM on the grape bunches was significantly reduced compared with the control by treatment with Bordeaux mixture, laminarin combined with Saccharomyces spp. extract and low copper, and 0.5 and $0.8 \%$ chitosan by $76,71,76$, and $82 \%$, respectively. The disease severity was reduced only by treatment with $0.8 \%$ chitosan.

Soon after the harvesting of the grape berries on 24 September 2012, where all of the leaves of the control grapevines were infected, there was a significant reduction in disease incidence, disease severity, and McKinney index compared with the control for treatment with Bordeaux mixture, copper hydroxide, laminarin combined with low copper without and with Saccharomyces spp. extracts, and 0.5 and $0.8 \%$ chitosan treatments (Table 2). The disease incidence was reduced compared with the control by these treatments by 96,95 , $75,67,56$, and $81 \%$, respectively. The McKinney index showed similar trends, with disease reductions compared with the control of $98,98,85,77,68$, and $90 \%$, respectively.

Considering all of the disease assessments, the rank analysis (Romanazzi et al. 2009) provided the following order of effectiveness of the treatments on the grapevine leaves and the grape bunches. On leaves: $0.8 \%$ chitosan $>$ copper hydroxide $>$ laminarin combined with low copper $=0.5 \%$ chitosan $>$ Bordeaux mixture $>$ laminarin combined with Saccharomyces spp. extracts $>$ control $>$ laminarin combined with Saccharomyces spp. extracts and low copper $>$ bentonite $>$ laminarin combined with microorganisms $>$ laminarin. On grape bunches: $0.8 \%$ chitosan $>$ Bordeaux mixture $>0.5 \%$ chitosan $>$ copper hydroxide $>$ laminarin combined with Saccharomyces spp. extracts $=$ laminarin combined with low copper $>$ laminarin combined with Saccharomyces spp. extracts and low copper $>$ laminarin combined with microorganisms $>$ control $>$ bentonite $>$ laminarin.

Evaluation of GDM infection: Second year. The first symptoms of GDM appeared on the leaves in early June 2013, and the disease assessments were carried out weekly from 7 June to 31 July 2013. On 11 July 2013, treatment with Bordeaux mixture, copper hydroxide, and 0.5 and $0.8 \%$ chitosan had significantly reduced disease incidence compared with the control by $82,40,59$, and $53 \%$, respectively (Table 3 ). In the same assessment, the McKinney index was also reduced compared with the control by treatment with laminarin combined with Saccharomyces spp. extracts or with low copper. In more detail, the treatment with Bordeaux mixture, copper hydroxide, laminarin combined with Saccharomyces spp. extracts, laminarin combined with low copper, and 0.5 and $0.8 \%$ chitosan resulted in reductions in the McKinney index compared with the control of 91, 62, $38,33,75$, and $72 \%$, respectively. Disease severity was significantly reduced compared with the control by with Bordeaux mixture, copper hydroxide, laminarin combined with low copper, vermicompost extract, and 0.5 and $0.8 \%$ chitosan.

The disease incidence on grape bunches recorded on 11 July 2013 was significantly reduced compared with the control by treatment with Bordeaux mixture, laminarin combined with Saccharomyces spp. extracts, laminarin combined with low copper, and 0.5 and $0.8 \%$ chitosan by $86,37,33,66$, and $75 \%$, respectively. Considering the McKinney index, significantly superior disease control compared with the control was observed after treatment with Bordeaux mixture, laminarin combined with Saccharomyces spp. extracts, and 0.5 and $0.8 \%$ chitosan, with disease reductions compared with the control of $90,49,71$, and $81 \%$, respectively. Disease severity was significantly reduced compared with the control by treatment with Bordeaux mixture and 0.5 and $0.8 \%$ chitosan.

The last survey of GDM on the grapevine leaves on 31 July 2013 revealed a further increase in the disease pressure. Grapevines treated with Bordeaux mixture, copper hydroxide, laminarin, and 0.5 and $0.8 \%$ chitosan showed significant reductions in GDM compared with

Table 3. (continued from preceding page)

\begin{tabular}{|c|c|c|c|c|c|}
\hline \multicolumn{3}{|c|}{31 July 2013} & \multicolumn{3}{|c|}{30 August 2013} \\
\hline \multicolumn{3}{|c|}{ Leaves } & \multicolumn{3}{|c|}{ Grape bunches } \\
\hline DI (\%) & Sev (1-10) & MI (\%) & DI (\%) & Sev (1-7) & MI (\%) \\
\hline $18.8 \pm 3.1 \mathrm{e}$ & $2.0 \pm 0.3 \mathrm{f}$ & $3.8 \pm 0.6 \mathrm{f}$ & $17.9 \pm 14.9 \mathrm{c}$ & $1.5 \pm 1.3 \mathrm{~d}$ & $5.2 \pm 5.4 \mathrm{e}$ \\
\hline $57.5 \pm 11.1 \mathrm{c}$ & $2.7 \pm 0.2 \mathrm{de}$ & $15.7 \pm 2.3 \mathrm{~d}$ & $61.7 \pm 18.5 \mathrm{ab}$ & $4.4 \pm 1.4 \mathrm{bc}$ & $39.8 \pm 17.7 \mathrm{~cd}$ \\
\hline $92.1 \pm 10.0 \mathrm{~b}$ & $5.4 \pm 1.6 \mathrm{a}$ & $50.3 \pm 18.6 \mathrm{a}$ & $68.4 \pm 20.6 \mathrm{ab}$ & $5.4 \pm 1.2 \mathrm{ab}$ & $53.9 \pm 20.6 \mathrm{abc}$ \\
\hline $97.9 \pm 1.5 \mathrm{a}$ & $3.2 \pm 0.1 \mathrm{~d}$ & $31.2 \pm 0.7 \mathrm{c}$ & $62.6 \pm 26.3 \mathrm{ab}$ & $3.8 \pm 1.6 \mathrm{c}$ & $35.6 \pm 19.7 \mathrm{~d}$ \\
\hline $98.0 \pm 1.0 \mathrm{ab}$ & $4.1 \pm 1.1 \mathrm{c}$ & $40.3 \pm 11.2 b c$ & $59.9 \pm 26.0 \mathrm{~b}$ & $5.2 \pm 0.9 \mathrm{ab}$ & $46.2 \pm 23.6 \mathrm{bcd}$ \\
\hline $98.8 \pm 1.5 \mathrm{a}$ & $4.7 \pm 0.4 \mathrm{abc}$ & $46.4 \pm 4.0 \mathrm{ab}$ & $78.5 \pm 24.5 \mathrm{ab}$ & $5.3 \pm 0.9 \mathrm{ab}$ & $60.5 \pm 23.2 \mathrm{ab}$ \\
\hline $98.2 \pm 1.9 \mathrm{a}$ & $4.4 \pm 0.9 \mathrm{bc}$ & $43.6 \pm 9.0 \mathrm{ab}$ & $72.9 \pm 21.2 \mathrm{ab}$ & $5.2 \pm 1.0 \mathrm{ab}$ & $55.7 \pm 22.0 \mathrm{abc}$ \\
\hline $97.3 \pm 2.0 \mathrm{ab}$ & $4.7 \pm 0.2 \mathrm{abc}$ & $45.8 \pm 2.8 \mathrm{ab}$ & $80.9 \pm 21.5 \mathrm{a}$ & $5.8 \pm 0.9 \mathrm{a}$ & $67.7 \pm 22.8 \mathrm{a}$ \\
\hline $50.8 \pm 10.6 \mathrm{~cd}$ & $2.4 \pm 0.6 \mathrm{ef}$ & $11.9 \pm 3.4 \mathrm{de}$ & $32.3 \pm 27.1 \mathrm{c}$ & $2.2 \pm 1.4 \mathrm{~d}$ & $13.4 \pm 16.4 \mathrm{e}$ \\
\hline $39.5 \pm 18.3 \mathrm{~d}$ & $2.3 \pm 0.3$ ef & $9.1 \pm 3.6 \mathrm{e}$ & $32.7 \pm 27.3 \mathrm{c}$ & $2.0 \pm 1.6 \mathrm{~d}$ & $12.4 \pm 15.0 \mathrm{e}$ \\
\hline $98.9 \pm 10.3 \mathrm{a}$ & $5.2 \pm 1.0 \mathrm{ab}$ & $51.9 \pm 10.3 \mathrm{a}$ & $80.4 \pm 18.4 \mathrm{a}$ & $5.6 \pm 1.0 \mathrm{a}$ & $64.9 \pm 20.1 \mathrm{a}$ \\
\hline
\end{tabular}


the control of $81,42,9,49$, and $60 \%$, respectively (Table 3 ). The McKinney index was not significantly different compared with the control in the grapevines treated with laminarin alone or laminarin combined with Saccharomyces spp. extracts and low copper, or with microorganisms, and in those treated with vermicompost extract. However, the McKinney index again showed significant reductions compared with the control for treatment with Bordeaux mixture, copper hydroxide, laminarin combined with Saccharomyces spp.
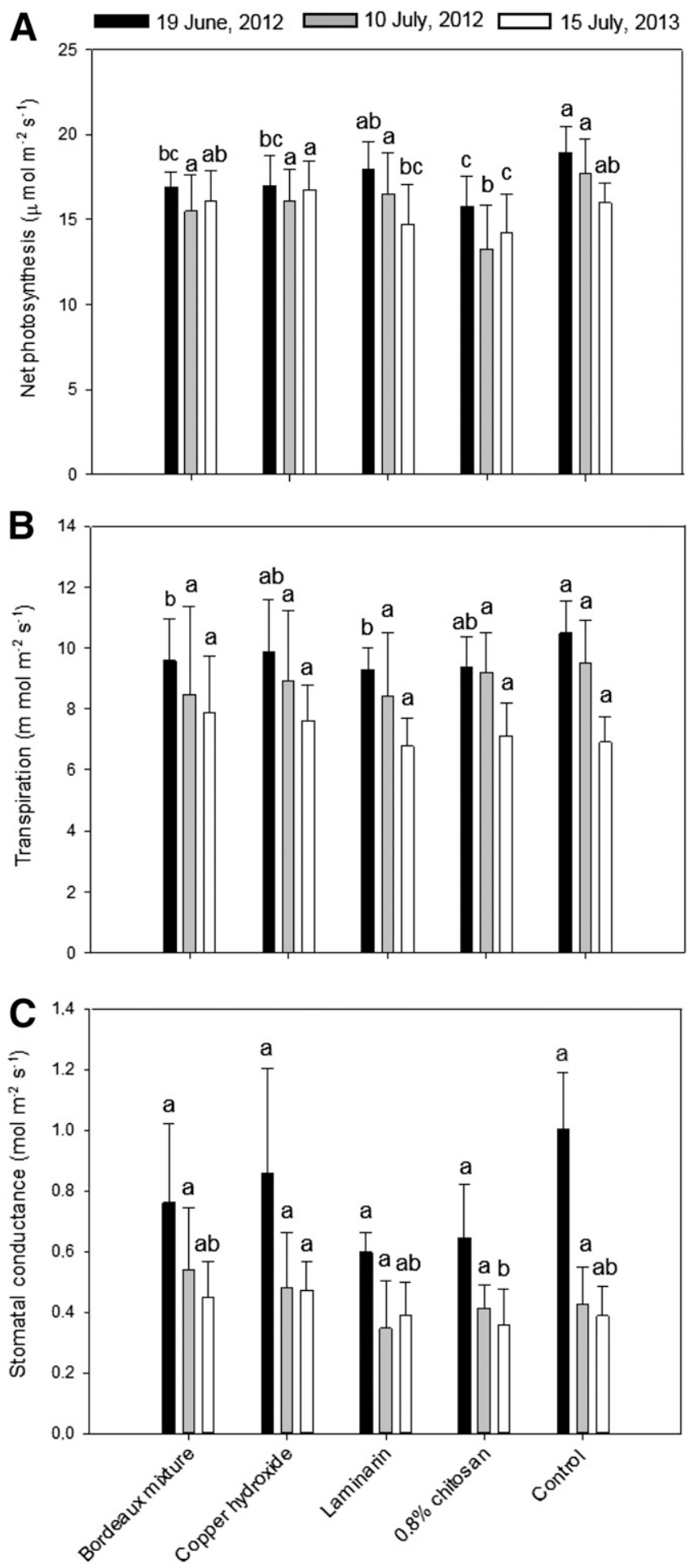

Fig. 2. A, Net photosynthesis; B, transpiration; and C, stomatal conductance for the leaves of the grapevines treated with Bordeaux mixture, copper hydroxide, laminarin, $0.8 \%$ chitosan, and untreated control, as recorded on 19 June 2012, 10 July 2012, and 15 July 2013, as indicated. Data are means \pm standard deviation. Means for the same day with different letters are significantly different (Tukey's honestly significant difference; $\alpha<0.05$ ). extracts, laminarin combined with low copper, and 0.5 and $0.8 \%$ chitosan of $93,70,40,22,82$, and $77 \%$, respectively. As indicated by the McKinney index, the disease severity was significantly reduced compared with the control in grapevines treated with Bordeaux mixture, copper hydroxide, laminarin combined with Saccharomyces spp. extracts, laminarin combined with low copper, and 0.5 and $0.8 \%$ chitosan.

The disease incidence on grape bunches recorded on 30 August 2013 was significantly reduced compared with the control by treatment with Bordeaux mixture, laminarin combined with low copper, and 0.5 and $0.8 \%$ chitosan by $78,26,60$, and $59 \%$, respectively. As indicated by the McKinney index, significant reductions compared with the control were also observed for treatment with copper hydroxide and with laminarin combined with Saccharomyces spp. extracts. The highest McKinney index reductions compared with the control were observed in the grapevines treated with Bordeaux mixture, copper hydroxide, laminarin combined with Saccharomyces spp. extracts, laminarin combined with low copper, and 0.5 and $0.8 \%$ chitosan at $92,39,45,29,79$, and $81 \%$, respectively. Significant reductions in disease severity compared with the control were observed in the grapevines treated with Bordeaux mixture, copper hydroxide, laminarin combined with Saccharomyces spp. extracts, laminarin combined with low copper, and 0.5 and $0.8 \%$ chitosan (Table 3).

Considering all of the disease assessments here, the rank analysis provided the following order of effectiveness of these treatments for the grapevine leaves: Bordeaux mixture $>0.8 \%$ chitosan $>$ laminarin combined with low copper $>0.5 \%$ chitosan $>$ vermicompost extract $=$ laminarin combined with Saccharomyces spp. extracts > copper hydroxide $>$ laminarin combined with Saccharomyces spp. extracts and low copper $>$ laminarin combined with microorganisms $>$ control $>$ laminarin. On the grape bunches, we recorded, by order of effectiveness: Bordeaux mixture $>0.8 \%$ chitosan $>0.5 \%$ chitosan $>$ laminarin combined with Saccharomyces spp. extracts $>$ copper hydroxide > laminarin combined with low copper > laminarin combined with microorganisms $>$ laminarin combined with Saccharomyces spp. extracts and low copper $>$ laminarin $>$ control $>$ vermicompost extract.

Physiological and growth parameters of the grapevines. The net photosynthesis recorded on 19 June 2012 for the leaves of the control grapevines was approximately $17.3 \mu \mathrm{mol} \mathrm{m} \mathrm{m}^{-2} \mathrm{~s}^{-1}$, which was higher than for the leaves treated with Bordeaux mixture, copper hydroxide, and $0.8 \%$ chitosan. The lowest net photosynthesis was recorded for the leaves of the grapevines treated with $0.8 \%$ chitosan (Fig. 2A). For the measurement of 10 July 2012, the net photosynthesis of the leaves of the grapevines treated with $0.8 \%$ chitosan was the lowest and was significantly decreased compared with the other treatments. In the following year, 2013, for the measurements carried out on 15 July, the highest net photosynthesis was recorded for the leaves of the grapevines treated with copper hydroxide while the lowest was obtained for those treated with $0.8 \%$ chitosan, which was significantly different compared with the untreated control (Fig. 2A). On 19 June 2012, the treatment of the grapevines with Bordeaux mixture and laminarin resulted in decreased leaf transpiration compared with the control (Fig. 2B). On 10 July 2012 and 15 July 2013, there were no significant differences in leaf transpiration among the treatments, although a tendency toward reduced leaf transpiration rate was recorded for grapevines treated with laminarin (Fig. 2B). Also, on 19 June and 10 July 2012, minimal stomatal conductance was recorded on the grapevines treated with laminarin. However, for the data recorded on 15 July 2013, higher stomatal conductance occurred after treatment with Bordeaux mixture and copper hydroxide compared with $0.8 \%$ chitosan, although none of the treatments differed significantly from the control (Fig. 2C).

The total chlorophyll contents (i.e., chlorophyll a plus b) of the leaves treated with Bordeaux mixture and laminarin were higher than for the leaves of the untreated grapevines on 7 September 2012. In the second year, on 15 July 2013, the leaves treated with Bordeaux mixture showed total chlorophyll content higher than those treated with laminarin and $0.8 \%$ chitosan, although none of the treatments were 
significantly different from the control (Fig. 3A). On 1 August 2013, treatment with Bordeaux mixture and copper hydroxide increased the chlorophyll content compared with the untreated control.

In 2012, treatment with $0.8 \%$ chitosan led to a significant area decrease of mature leaves compared with all of the other treatments (Fig. 3B). The leaf fresh weight of these chitosan-treated grapevines was significantly lower than the control and the treatment with Bordeaux mixture, while the dry weight was only significantly lower than the treatment with Bordeaux mixture (Fig. 3C).

Shoot growth was measured only in the first year (2012), and significant differences among the treatments were observed only in the
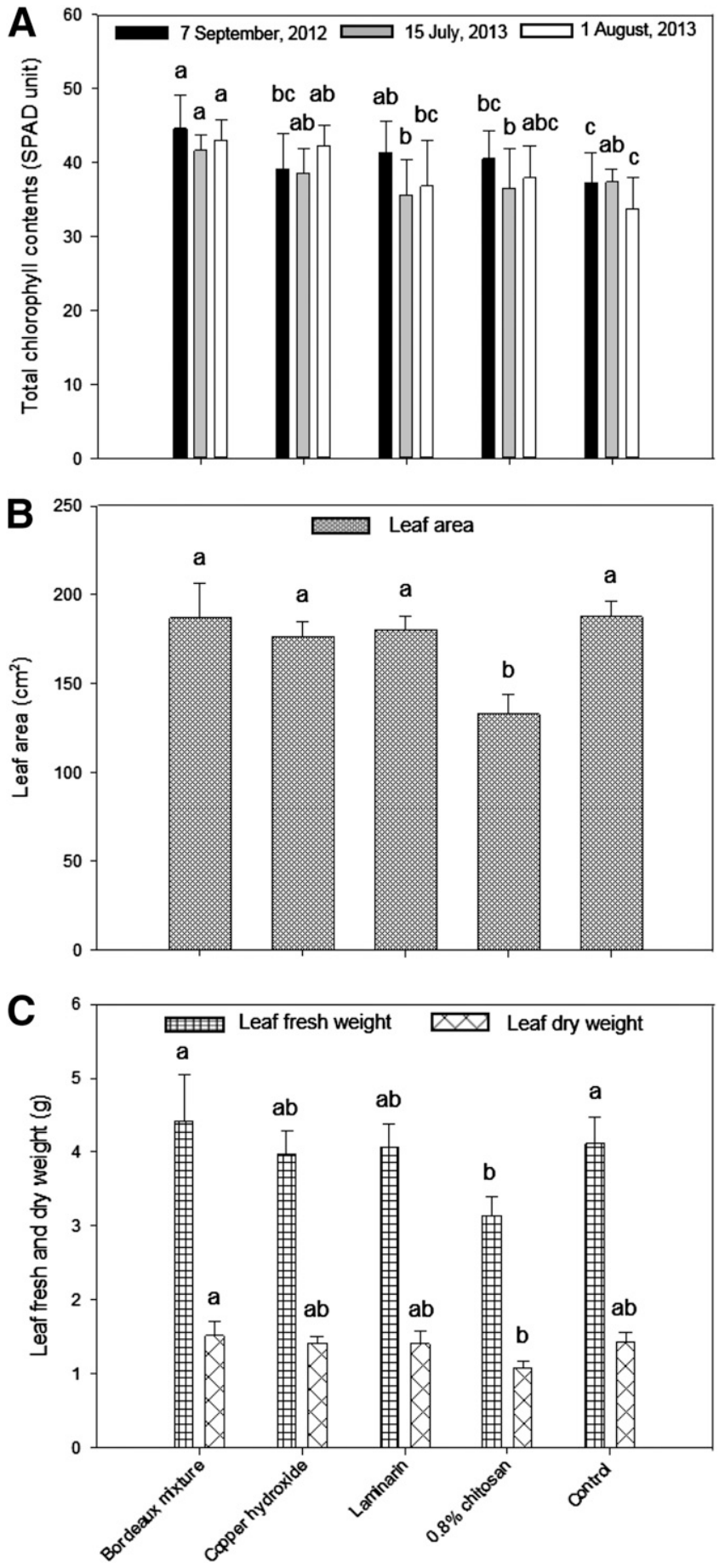

Fig. 3. A, Total chlorophyll $(a+b)$ content; $\mathbf{B}$, leaf area; and $\mathbf{C}$, leaf fresh and dry weights for the leaves of the grapevines treated with Bordeaux mixture, copper hydroxide, laminarin, $0.8 \%$ chitosan, and untreated control. Data are means \pm standard deviation. Means for the same date with different letters are significantly different (Tukey's honestly significant difference; $\alpha<0.05$ ). data for 12 and 25 June 2012 whereas, in the other three assessments in 2012, there were no statistical differences recorded (Table 4). On 12 June 2012, the shoot lengths of the grapevines treated with bentonite were significantly greater than those of the control grapevines and of the grapevines treated with Bordeaux mixture, copper hydroxide, laminarin alone, laminarin combined with Saccharomyces spp. extracts, or combined with Saccharomyces extracts and low copper, and 0.5 and $0.8 \%$ chitosan. On 25 June 2012, the shoots of the grapevines treated with bentonite were longer than those treated with laminarin combined with low copper, although the shoot lengths recorded in the treated grapevines were not significantly different from the untreated control.

The treatment with fungicides did not influence dormant pruning weights recorded on 11 March 2014 as compared with the control. However, the application of copper hydroxide induced a higher shoot growth compared with $0.8 \%$ chitosan (Fig. 4 ).

Grape production. Grape production was not affected by the treatments in terms of either quantity or quality (Table 5). The production per plant and the quality parameters of the berry juice musts,

Table 4. Shoot lengths on the indicated dates for the grapevines treated with the different formulations during the 2012 season $^{\mathrm{y}}$

\begin{tabular}{lccccc}
\hline & \multicolumn{5}{c}{ Shoot length (cm) } \\
\cline { 2 - 6 } Treatment $^{\mathbf{z}}$ & $\mathbf{6 ~ J u n e}$ & $\mathbf{1 2}$ June & 18 June & 25 June & 2 July \\
\hline $\begin{array}{c}\text { Bordeaux } \\
\text { mixture }\end{array}$ & $68 \pm 22 \mathrm{a}$ & $101 \pm 20 \mathrm{~b}$ & $113 \pm 21 \mathrm{a}$ & $137 \pm 23 \mathrm{ab}$ & $153 \pm 26 \mathrm{a}$ \\
$\begin{array}{c}\text { Copper } \\
\text { hydroxide }\end{array}$ & $67 \pm 22 \mathrm{a}$ & $102 \pm 17 \mathrm{~b}$ & $112 \pm 17 \mathrm{a}$ & $134 \pm 26 \mathrm{ab}$ & $152 \pm 23 \mathrm{a}$ \\
$\begin{array}{l}\text { Laminarin } \\
\text { Laminarin+Ext }\end{array}$ & $66 \pm 24 \mathrm{a}$ & $100 \pm 17 \mathrm{~b}$ & $117 \pm 21 \mathrm{a}$ & $139 \pm 29 \mathrm{ab}$ & $154 \pm 34 \mathrm{a}$ \\
$\begin{array}{l}\text { Laminarin+Cu } \\
\text { Laminarin+ }\end{array}$ & $61 \pm 26 \mathrm{a}$ & $97 \pm 21 \mathrm{ab}$ & $119 \pm 16 \mathrm{a}$ & $147 \pm 25 \mathrm{ab}$ & $156 \pm 25 \mathrm{a}$ \\
$\quad$ Cu+Ext+Cu & $55 \mathrm{a}$ & $101 \pm 15 \mathrm{~b}$ & $114 \pm 18 \mathrm{a}$ & $127 \pm 24 \mathrm{~b}$ & $145 \pm 32 \mathrm{a}$ \\
$\begin{array}{c}\text { Laminarin+ } \\
\text { Mix }\end{array}$ & $64 \pm 26 \mathrm{a}$ & $106 \pm 19 \mathrm{ab}$ & $119 \pm 20 \mathrm{a}$ & $138 \pm 22 \mathrm{ab}$ & $148 \pm 24 \mathrm{a}$ \\
$\begin{array}{c}\text { Bentonite } \\
0.5 \% \text { chitosan }\end{array}$ & $69 \pm 25 \mathrm{a}$ & $113 \pm 18 \mathrm{a}$ & $119 \pm 18 \mathrm{a}$ & $152 \pm 31 \mathrm{a}$ & $160 \pm 26 \mathrm{a}$ \\
$0.8 \%$ chitosan & $67 \pm 24 \mathrm{a}$ & $99 \pm 14 \mathrm{~b}$ & $111 \pm 19 \mathrm{a}$ & $135 \pm 24 \mathrm{ab}$ & $154 \pm 25 \mathrm{a}$ \\
Control & $63 \pm 26 \mathrm{a}$ & $103 \pm 15 \mathrm{~b}$ & $112 \pm 26 \mathrm{a}$ & $136 \pm 40 \mathrm{ab}$ & $158 \pm 37 \mathrm{a}$ \\
\hline
\end{tabular}

y Data are means \pm standard deviation. Values followed by different letters in the same column are significantly different (Tukey's honestly significant difference; $\alpha<0.05$ ).

${ }^{\mathrm{z}}$ Ext $=$ microbial extract of Saccharomyces spp., $\mathrm{Cu}=$ copper hydroxide or copper oxide, and Mix = microorganisms (Glomus spp., Bacillus subtilis, Streptomyces spp., Trichoderma spp., and Pichia pastoris).

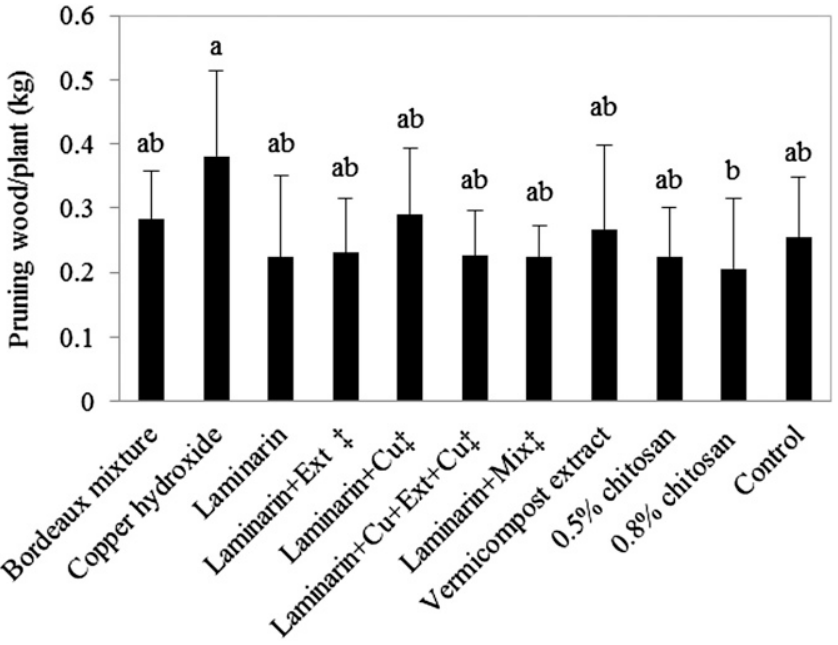

Fig. 4. Weight of pruned branches from the grapevines according to the treatments indicated, as recorded on 11 March 2014. Data are means \pm standard deviation. Means with different letters are significantly different (Tukey's honestly significant difference, $\alpha<0.05$ ). 
such as the titratable acidity and sugar concentration, were not different among the treatments. The only difference seen was for the $\mathrm{pH}$ of the berry juice from the grapevines treated with 0.5 and $0.8 \%$ chitosan, which was lower than that of the grapevines treated with laminarin alone or combined with low copper.

\section{Discussion}

On the basis of our field trial, and although the treatment with the copper-containing Bordeaux mixture provided the best crop protection against GDM, we found good effectiveness of treatment with chitosan as an alternative, copper-free compound. In other studies that have been carried out on grapevines to determine the effectiveness against GDM of treatments with low-rate copper formulations and alternative compounds such as chitosan and bentonite, the alternative products tested did not guarantee good crop protection, even under conditions of low disease pressure (Dagostin et al. 2011; La Torre et al. 2010; Romanazzi et al. 2010). During the present trials, treatment with chitosan provided the best plant protection against GDM compared with the other alternative products applied.

The 2 years over which this trial was conducted were characterized by different climatic conditions and, consequently, the data obtained relating to the parameters examined were very different in each year. The surveys that were conducted during these growing seasons allowed the differences in the effectiveness of the treatments with the copper-based products and the natural compounds applied to the vegetation to be highlighted. Between the treatments with the two copper-based products, Bordeaux mixture provided better protection against GDM than copper hydroxide under both the lower (2012) and higher (2013) disease pressure. However, the amounts of copper for the treatment with Bordeaux mixture using this strategy was twice that allowed in organic agriculture in the European Union. The treatment with copper hydroxide in 2012 was as effective as Bordeaux mixture whereas, in 2013, under the higher disease pressure, the treatment with copper hydroxide did not adequately contain the GDM. This lack of effectiveness of the treatment with copper hydroxide might have been due to the frequent rainfall that occurred throughout the growing season in 2013, which would have caused leaf run-off of the copper hydroxide, which is less rainfast than Bordeaux mixture.

Among the natural compounds, good disease reduction compared with the control occurred with the treatments with chitosan, which was also the case under the higher disease pressure in 2013, where the higher concentration of chitosan $(0.8 \%)$ was more effective than copper hydroxide. Some studies have shown that foliar application of chitosan on grapevine leaves can significantly reduce infections caused by Plasmopara viticola (Aziz et al. 2006; Maia et al. 2012). The effectiveness of chitosan for the reduction of GDM incidence and severity for different plant species has also been reported when applied as a foliar spray or a seed treatment under both greenhouse and field conditions; for example, for Pseudoperonospora cubensis on cucumber (Farouk et al. 2008), Sclerospora graminicola on pearl millet (Sharathchandra et al. 2004; Manjunatha et al. 2008), and Plasmopara halstedii on sunflower (Nandeeshkumar et al. 2008) through enhanced expression of genes related to defense proteins.

The potential for reduced infections of $P$. viticola through treatment with the $\beta$-1,3-glucan laminarin depended on its combination with other compounds and on the type of compound added. Under the higher disease pressure in 2013 , the treatment with laminarin combined with Saccharomyces spp. extracts provided less incidence of GDM infection compared with the control whereas, under the lower disease pressure in 2012, treatment with laminarin combined with copper at a low concentration and the alternation of these two combinations were moderately effective. Treatment with laminarin alone or in combination with microorganisms of the rhizosphere, which included fungi, rhizobacteria, and a yeast, provided insufficient protection for the grapevines, with disease infection levels almost equal to those of the untreated (control) grapevines. However, the results obtained in the present study for the treatment with laminarin alone are not in agreement with those of other studies, where treatment with $\beta$-1,3-glucan was reported to elicit a variety of plant defense reactions that inhibit the development of $P$. viticola and $B O-$ trytis cinerea on grapevines (Aziz et al. 2003). Of note, in other studies, treatment with laminarin has not always ensured adequate protection of plants (e.g., on tobacco against Phytophthora parasitica var. nicotianae; Mercier et al. 2001).

The combination of Saccharomyces spp. extracts with laminarin led to greater reductions in GDM compared with the control than for the treatment with laminarin alone. This is in agreement with other field trials, where elicitors derived from the yeast Saccharomyces cerevisiae had reduced powdery mildew infections in barley (Reglinski et al. 1994).

Regarding the treatment with the microorganisms from the rhizosphere, which use was proposed also in the control of GDM, in the present study they were applied to the vegetation rather than to the soil, and this might have been responsible for their lack of protection against GDM, which is much more aggressive within a short period. These microorganisms can survive well in the soil, where there is higher humidity, whereas they might have had difficulties in their survival on the grapevine leaves.

Applying ineffective products via a foliar spray can alter canopy microclimate to favor disease development and this might explain why, in some instances, the treatments with laminarin alone and with laminarin combined with the microorganisms gave GDM incidence higher than for the control grapevines.

The treatments with the combination of laminarin and low copper concentrations appeared to be sufficient to control low disease pressure (i.e., in 2012); a good solution instead of treatment with the common agronomic practices that use full doses of copper. In particular, the treatments with Bordeaux mixture and copper hydroxide used copper at 11 and $5.9 \mathrm{~kg} / \mathrm{ha} / \mathrm{year}$, respectively, while the treatment

Table 5. Quantity and quality of the grape production parameters from the grapevines treated with the different formulations during the 2012 season ${ }^{y}$

\begin{tabular}{|c|c|c|c|c|}
\hline Treatment $^{\mathrm{z}}$ & Production/plant (g) & Sugar content (\% Brix) & Total acidity (g/liter) & pH \\
\hline Bordeaux mixture & $2,459 \pm 428$ & $20.30 \pm 1.27$ & $5.22 \pm 0.62$ & $3.21 \pm 0.05 \mathrm{ab}$ \\
\hline Copper hydroxide & $2,194 \pm 253$ & $20.80 \pm 0.00$ & $5.18 \pm 0.27$ & $3.19 \pm 0.00 \mathrm{ab}$ \\
\hline Laminarin & $2,055 \pm 458$ & $20.65 \pm 0.49$ & $5.73 \pm 0.35$ & $3.27 \pm 0.05 \mathrm{a}$ \\
\hline Lamaminarin+Ext & $1,978 \pm 268$ & $19.95 \pm 1.20$ & $5.46 \pm 0.08$ & $3.24 \pm 0.01 \mathrm{ab}$ \\
\hline Laminarin+Cu & $2,298 \pm 483$ & $21.30 \pm 0.42$ & $5.82 \pm 0.44$ & $3.27 \pm 0.04 \mathrm{a}$ \\
\hline Laminarin $+\mathrm{Cu}+\mathrm{Ext}+\mathrm{Cu}$ & $2,357 \pm 141$ & $20.70 \pm 0.42$ & $5.50 \pm 1.35$ & $3.19 \pm 0.08 \mathrm{ab}$ \\
\hline Laminarin+Mix & $1,815 \pm 277$ & $20.20 \pm 1.13$ & $4.89 \pm 1.40$ & $3.25 \pm 0.01 \mathrm{ab}$ \\
\hline Bentonite & $1,950 \pm 555$ & $19.85 \pm 1.06$ & $4.65 \pm 0.97$ & $3.21 \pm 0.05 \mathrm{ab}$ \\
\hline $0.5 \%$ chitosan & $2,212 \pm 286$ & $20.50 \pm 0.71$ & $4.89 \pm 0.70$ & $3.14 \pm 0.01 b$ \\
\hline $0.8 \%$ chitosan & $2,260 \pm 442$ & $20.40 \pm 0.57$ & $4.82 \pm 0.45$ & $3.14 \pm 0.01 b$ \\
\hline Control & $1,732 \pm 583$ & $19.85 \pm 0.35$ & $4.77 \pm 0.81$ & $3.21 \pm 0.01 \mathrm{ab}$ \\
\hline
\end{tabular}

y Data are means \pm standard deviation. Values followed by different letters in the same column are significantly different (Tukey's honestly significant difference; $\alpha<0.05)$.

${ }^{\mathrm{z}}$ Ext $=$ microbial extract of Saccharomyces $\mathrm{spp} ., \mathrm{Cu}=$ copper hydroxide or copper oxide, and Mix = microorganisms (Glomus spp., Bacillus subtilis, Streptomyces spp., Trichoderma spp., and Pichia pastoris). 
with laminarin combined with low copper, and the alternation of this treatment with laminarin combined with Saccharomyces extract, used copper at only 1 and $0.4 \mathrm{~kg} / \mathrm{ha} /$ year, respectively. Because some of the disease assessments in the year with low disease pressure showed no statistical differences among these four treatments, this showed that the level of copper can be reduced for the control of GDM infections when the seasonal disease pressure is low. Indeed, it has already been shown that the combination of treatments with low rates of copper and with microorganisms can be effective against GDM (Puopolo et al. 2014). On the other hand, the treatment with $0.8 \%$ chitosan, which uses no copper at all, gave good levels of protection, although these also remained lower than those obtained for the treatment with Bordeaux mixture under the higher disease pressure in 2013

The bentonite mixture, which here included bentonite, lithothamne, and potassic stone meal, is characterized by a content of potassium $\left(2.6 \% \mathrm{~K}_{2} \mathrm{O}\right)$, mesoelements $(18.5 \% \mathrm{CaO}$ and $3.1 \% \mathrm{Mg})$, and microelements associated with silicate and sulfur, and it represents a basic mixture used in biodynamic agriculture without problems for wine quality and stability. However, in the present study, the treatment with bentonite under the conditions of low disease incidence was not effective for the prevention of GDM infection. As with another organic compound used in the present study, the vermicompost extract is composed of Lumbricus spp. humus that is enriched in plant essences, including nettle, garlic, horsetail, wormwood, onion, eucalyptus, thyme, yarrow, oregano, marjoram, and propolis, and it is characterized by strong fungicidal and insecticidal properties. Both here and in a study carried out by Dagostin et al. (2011), treatment with this vermicompost has proven to be ineffective in controlling GDM.

The influences of the treatment with chitosan led to lower net photosynthesis, stomatal conductance, leaf area, and weight of leaves and pruned branches. These side effects of chitosan are very risky for obtaining high berry quality but it can be favorable in modern viticulture where, increasingly, there is the search for techniques to better manage excess plant vigor (Chaves et al. 2007). Maintenance of the most cost-effective balance between vegetative and reproductive growth is the main aim to be achieved. Grapevines that show excessive vegetative vigor are likely to produce less fruit of reduced quality, although grapevines with inadequate vigor might be compromised in terms of their potential yield. In relation to the optimization of water use by the plant, it is important to note that transpiration rate was lower in the grapevines treated with Bordeaux mixture and laminarin compared with the untreated control. It has been shown that treatment with laminarin can induce significant inhibition of stomatal opening (Allègre et al. 2009), data that agree with the present study, considering that stomatal conductance is integral to the calculations of transpiration at the leaf level.

Chlorophyll content usually decreases in leaves that show disease symptoms (Endeshaw et al. 2012, 2014; Lopes and Berger 2001). This is confirmed in the present study because, in both years here, the leaves treated with Bordeaux mixture, which is the product that provided the best protection against GDM, showed the highest pigment content.

The mixture of bentonite, lithothamne, and potassic stone meal that was sprayed on the grapevines increased their growth, which resulted in shoots that were longer than those seen for the other treatments.

Chitosan can be considered as an alternative product to copper, especially in organic farming. Chitosan hydrochloride was approved for use in agriculture as a plant protection product by European Commission Regulation (EU) number 563/2014 of 23 May 2014, in accordance with Regulation (EC) number 1107/2009 of the European Parliament and Council. Some of the other alternative products examined here might be useful as alternations or mixtures with those based on copper for periods of the growing season that are characterized by low disease pressure, to limit the use of copper. However, it remains necessary to carry out large-scale trials to verify the effectiveness of these GDM management strategies, and to further define their effects on the quality of the wines that are produced.

\section{Acknowledgments}

We thank L. Flamini and S. Nardi of SFR-ASSAM, Marche region, who promoted the project "Control of grapevine downy mildew with fungicides for organic agriculture"; A. Piunti for useful discussions on the subject; D. Coppa from Terre Cortesi-Moncaro for help in the planning and running of the trials; F. Giammarino, F. Del Re, and G. Del Gobbo for their help with the field treatments; and M. Bravett and M. Bastianelli for their collaboration on the measurements of the physiological parameters in the first year of the investigation.

\section{Literature Cited}

Alfonzo, A., Piccolo, S. L., Conigliaro, G., Ventorino, V., Burruano, S., and Moschetti, G. 2012. Antifungal peptides produces by Bacillus amyloliquefaciens AG1 active against grapevine fungal pathogens. Ann. Microbiol. 62:1593-1599.

Allègre, M., Héloir, M. C., Trouvelot, S., Daire, X., Pugin, A., Wendehenne, D., and Adrian, M. 2009. Are grapevine stomata involved in the elicitor-induced protection against downy mildew? Mol. Plant-Microbe Interact. 22:977-986.

Aziz, A., Poinssot, B., Daire, X., Adrian, M., Bézier, A., Lambert, B., Joubert, J.-M., and Pugin, A. 2003. Laminarin elicits defense responses in grapevine and induces protection against Botrytis cinerea and Plasmopara viticola. Mol. Plant-Microbe Interact. 16:1118-1128.

Aziz, A., Trotel-Aziz, P., Dhuicq, L., Jeandet, P., Couderchet, M., and Vernet, G. 2006. Chitosan oligomers and copper sulfate induce grapevine defense reactions and resistance to gray mold and downy mildew. Phytopathology 96:1188-1194.

Burruano, S., Alfonzo, A., Lo Piccolo, S., Conigliaro, G., Mondello, V., Torta, L. Moretti, M., and Assante, G. 2008. Interaction between Acremonium byssoides and Plasmopara viticola in Vitis vinifera. Phytopathol. Mediterr. 47:122-131.

Caffi, T., Rossi, V., and Bugiani, R. 2010. Evaluation of a warning system for controlling primary infections of grapevine downy mildew. Plant Dis. 94: 709-716.

Chaves, M. M., Santos, T. P., Souza, C. R., Ortuno, M. F., Rodrigues, M. L., Lopes, C. M., Maroco, J. P., and Pereira, J. S. 2007. Deficit irrigation in grapevine improves water-use efficiency while controlling vigour and production quality. Ann. Appl. Biol. 150:237-252.

Commission Regulation (EC) No 473/2002 of 15 March 2002 amending Annexes I, II and VI to Council Regulation (EEC) No 2092/91 on organic production of agricultural products and indications referring thereto on agricultural products and food-stuffs, and laying down detailed rules as regards the transmission of information on the use of copper compounds. Official Journal L 075:21-24.

Dagostin, S., Schärer, H. J., Pertot, I., and Tamm, L. 2011. Are there alternatives to copper for controlling grapevine downy mildew in organic viticulture? Crop Prot. 30:776-788

El Hadrami, A., Adam, L. R., El Hadrami, I., and Daayf, F. 2010. Chitosan in plant protection. Mar. Drugs 8:968-987.

Endeshaw, S. T., Murolo, S., Romanazzi, G., and Neri, D. 2012. Effects of Bois noir on carbon assimilation, transpiration, stomatal conductance of leaves and yield of Vitis vinifera cv. Chardonnay. Physiol. Plant 145:286-295.

Endeshaw, S. T., Sabbatini, P., Romanazzi, G., Schilder, A., and Neri, D. 2014 Effects of grapevine leafroll associated virus 3 infection on growth, leaf gas exchange, yield and basic fruit chemistry of Vitis vinifera L. cv. Cabernet Franc. Sci. Hortic. 170:228-236

Farouk, S., Ghoneem, K. M., and Abeer, A. A. 2008. Induction and expression of systemic resistance to downy mildew disease in cucumber by elicitors. Egypt. J. Phytopathol. 36:95-111.

Feliziani, E., Smilanick, J. L., Margosan, D. A., Mansour, M. F., Romanazzi, G., Gu, S., Gohil, H. L., and Rubio Ames, Z. 2013. Preharvest fungicide, potassium sorbate, or chitosan use on quality and storage decay of table grapes. Plant Dis. 97:307-314.

Gessler, C., Pertot, I., and Perazzoli, M. 2011. Plasmopara viticola: A review of knowledge on downy mildew of grapevine and effective disease management. Phytopathol. Mediterr. 50:3-44.

Harman, G. E., Howell, C. R., Viterbo, A., Chet, I., and Lorito, M. 2004 Trichoderma species - opportunistic, avirulent plant symbionts. Nat. Rev. Microbiol. 2:43-56.

Howell, G. S. 2001. Sustainable grape productivity and the growth-yield relationship: A review. Am. J. Enol. Vitic. 52:165-174.

Khan, W., Rayirath, U. P., Subramanian, S., Jithesh, M. N., Rayorath, P., Hodges, D. M., Critchley, A. T., Craigie, J. S., Norrie, J., and Prithiviraj, B. 2009 Seaweed extracts as biostimulants of plant growth and development. J. Plant Growth Regul. 28:386-399.

Lachhab, N., Sanzani, S., Adrian, M., Chiltz, A., Balacey, S., Boselli, M., Ippolito, A., and Poinssot, B. 2014. Soybean and casein hydrolysates induce grapevine immune responses and resistance against Plasmopara viticola. Front. Plant Sci. 5:716.

La Torre, A., Talocci, S., and Miele, M. 2010. Evaluation of anti-downy mildew effectiveness and economic sustainability of substances of natural origin. Petria 20:46-48.

Liu, X. G., Gao, K. X., Kang, Z. S., and He, B. L. 2007. Systemic resistance induced by biocontrol agents in plants and its biochemical and cytological mechanisms. Chin. J. Appl. Ecol. 18:1861-1868.

Lopes, D. B., and Berger, R. D. 2001. The effects of rust and anthracnose on the photosynthetic competence of diseased bean leaves. Phytopathology 91:212220. 
Maia, A. J., Leite, C. D., Botelho, R. V., Faria, C. M. D. R., and Machado, D. 2012. Chitosan as an option to control mildew in the sustainable vinegrowing. Semin. Cienc. Agrar. Londrina 33:2519-2530.

Mandal, K., Saravanan, R., Maiti, S., and Kothari, I. L. 2009. Effect of downy mildew disease on photosynthesis and chlorophyll fluorescence in Plantago ovata Forsk. J. Plant Dis. Prot. 116:164-168.

Manjunatha, G., Roopa, K. S., Prashanth, G. N., and Shetty, H. S. 2008. Chitosan enhances disease resistance in pearl millet against downy mildew caused by Sclerospora graminicola and defence-related enzyme activation. Pest Manage. Sci. 64:1250-1257.

McKinney, H. H. 1923. Influence of soil, temperature and moisture on infection of wheat seedlings by Helminthosporium sativum. J. Agric. Res. 26: 195-217.

Mercier, L., Lafitte, C., Borderies, G., Briand, X., Esquerré-Tugayé, M.-T., and Fournier, J. 2001. The algal polysaccharide carrageenans can act as an elicitor of plant defence. New Phytol. 149:43-51.

Mira de Orduña, R. 2010. Climate change associated effects on grape and wine quality and production. Food Res. Int. 43:1844-1855.

Nandeeshkumar, P., Sudisha, J., Ramachandra, K. K., Prakash, H. S., Niranjana, S. R., and Shekar, S. H. 2008. Chitosan induced resistance to downy mildew in sunflower caused by Plasmopara halstedii. Physiol. Mol. Plant Pathol. 72: 188-194.

Pontiroli, R., Rizzotti, R., and Zerbetto, F. 2001. Low rate copper formulations in control of grapevine downy mildew in Oltrepò Pavese. Inf. Fitopatol. 10:62-66.
Puopolo, G., Giovannini, O., and Pertot, I. 2014. Lysobacter capsici AZ78 can be combined with copper to effectively control Plasmopara viticola on grapevine. Microbiol. Res. 169:633-642.

Reglinski, T., Lyon, G. D., and Newton, A. C. 1994. Assessment of the ability of yeast-derived elicitors to control barley powdery mildew in the field. $\mathrm{Z}$. Pflanzenkrankh. Pflanzen. 101:1-10.

Romanazzi, G., Feliziani, E., Bautista Baños, S., and Sivakumar, D. 2016. Shelf life extension of fresh fruit and vegetables by chitosan treatment. Crit. Rev. Food Sci. Nutr. In press. doi:10.1080/10408398.2014.900474

Romanazzi, G., Mlikota Gabler, F., Margosan, D., Mackey, B. E., and Smilanick, J. L. 2009. Effect of chitosan dissolved in different acids on its ability to control postharvest gray mold of table grape. Phytopathology 99:1028-1036.

Romanazzi, G., Santini, M., Murolo, S., Masciulli, A., D’Ercole, G., and Patrizio, F. 2010. Evaluation of the effectiveness of copper formulations used at reduced rates and of alternative compounds in the control of Plasmopara viticola. Petria 20:9-12.

Rusjan, D., Strlic, M., Pucko, D., and Korosec-Koruza, Z. 2007. Copper accumulation regarding the soil characteristics in Sub-Mediterranean vineyards of Slovenia. Geoderma 141:111-118

Sharathchandra, R. G., Niranjan Raj, S., Shetty, N. P., Amruthesh, K. N., and Shekar Shetty, H. 2004. A chitosan formulation Elexa induces downy mildew disease resistance and growth promotion in pearl millet. Crop Prot. 23:881-888.

Speiser, B., Berner, A., Häseli, A., and Tamm, L. 2000. Control of downy mildew of grapevine with potassium phosphonate: Effectivity and phosphonate residues in wine. Biol. Agric. Hortic. 17:305-312. 